\title{
Study of Biogas Production with Organic Rubbish as Producing Material
}

\author{
Santosa $^{\# 1}$, Sandra ${ }^{\#}$, Omil Charmyn Chatib ${ }^{\#}$ and Asep Dian Prima * \\ \# Faculty of Agricultural Technology, Andalas University, Padang, Indonesia \\ E-mail: ${ }^{1}$ santosa764@yahoo.co.id
}

\begin{abstract}
* Production and Agricultural Machines and Equipments Management Laboratory, Agricultural Engineering Department,
\end{abstract}
Faculty of Agricultural Technology, Andalas University, Padang Indonesia

\begin{abstract}
This research had done at Production and Agricultural Machines and Equipments Management Laboratory at Agricultural Engineering, Faculty of Agricultural Technology, Andalas University, Padang City from November 2011 to March 2012. It intent to study about biogas physics parameters (to know about when the first time it producing biogas, biogas volume and pressure, relative humidity (RH), enviroment temperature, biogas energy) and chemical parameter such as producing material acidity degree (pH) in the beginning and last obsevation. It obsevation method has two different ways. First, using combination of 35 kgs radish and 35 cabbages rubbish as producing material. Second ways is using 70 kgs radish rubbish. Each way mixed by 4 liters EM4 as decomposer, 70 liters water, and observed for 30 days. The result showed in first way that biogas had produced first time at $9^{\text {th }}$ day with 554,4 kJ biogas energy, productivity is 0.47 liter biogas / $\mathrm{kg}$ producing material, $28.6^{\circ} \mathrm{C}$ environment temperature, 80.1 \% RH, 456.1 Pa biogas pressure, 6.1 starting $\mathrm{pH}$, and 6.6 last $\mathrm{pH}$. In second way had obtained that in $9^{\text {th }}$ day is first time biogas had produced with $537.6 \mathrm{~kJ}$ energy, productivity is 0.42 liter biogas / $\mathrm{kg}$ producing material, $28.2{ }^{\circ} \mathrm{C}$ environment temperature, $82.1 \%$ RH, 436.2 Pa biogas pressure, 6.3 starting $\mathrm{pH}$, and 6.8 last $\mathrm{pH}$.
\end{abstract}

Keywords — biogas, organic rubbish, EM4, radish, cabbage

\section{INTRODUCTION}

Indonesia faces the problem of energy crisis and increased waste. The energy crisis that hit the country is predicted to last until the next several years due to the use of large amounts of energy, while the energy is running low. Therefore, there will be scarcity to get it. In other words, it will eventually lead to an energy crisis. The use of energy from fossil fuels such as fuel (fuel oil) and LPG gas appeared to have a considerable effect. This is caused by the use of fuel that getting bigger, but the formation of this fuel requires a very long time, even until hundreds of years.

If the fuel use is increasingly getting bigger, then it could be predicted in a not too distant future this fuel can be decreased and even exhausted. To anticipate that, there is the need for new alternative energy that can be updated in a short time and can be done by everyone. The amount of waste in Indonesia is very large. Specifically for the amount of household waste, the amount generated in 2020 is expected to increase 5 times. This increase is not only due to population growth but also because of increased landfill waste per capita due to improved levels of economy and welfare. It is estimated that each person produces about half a kilogram of organic waste per day [9].

The application of alternative energy technology has been widely used at the moment, especially biogas. Many people think the biogas technology is complicated and needs a big cost. However, in reality the opinion is not true because the manufacturing of biogas reactors can usematerials and tools that exist in the surrounding environment. In addition to easy and low cost of manufacturing the reactor, biogas technology can suppress the spread of waste as it can be used as raw material for biogas, which is organic waste.

Thus, the application of biogas technology, at least on each household could answer the question ofthe solution to the energy dependence of the Indonesian population which is increasingly difficult to obtain and more expensive. In addition, the application of this technology can reduce the spreading of waste to create the clean and healthy environment. Biogas development in region that have the potential to produce it can also create new job opportunity.

Because the problem of waste is increasingly worrying and energy issues are increasingly scarce and expensive by 
the day, the authors wanted to do a research entitled study of biogas production with organic Waste as Producing Material.

This research is conducted with the aim to study physical and chemical parameters of biogas, which is for what, the onset timeof producing gas, find the volume and pressure of gas, temperature and environment $\mathrm{RH}$, the energy produced, the productivity of biogas produced, and the $\mathrm{pH}$ of the raw material.

The results of this research are expected to know the onset time of producing gas, temperature and environment $\mathrm{RH}$, the volume and pressure of gas, energy, productivity, and the $\mathrm{pH}$ of the raw material. In general, this research may be one solution to solve the waste problem and the energy crisis. Since the materials and how to manufacture tools is quite easy.

\section{METHODOLOGY}

\section{A. Materials and Tools}

Tools required in the manufacture of this device, i.e. 1 unit biogas reactor, 2 thermometers, cotton, knives, buckets, rubber and thick plastic.

The materials used in this research was 70 liters of organic waste that has been refined, i.e. each mix mustard and radish, 70 liters of water and EM4 8 quarts (4 liters for each treatment).

\section{B. Research Design}

This research was conducted with the observation of environment temperature, environment $\mathrm{RH}$, the volume and pressure of gas, energy, productivity, yield of biogas produced, and the $\mathrm{pH}$ of the raw material. Before the observation, first use knife to cut the raw material.

This form of biogas reactor three drums of which serves as a digester drum, insulator drum and collector biogas drum. Digester tank and insulator tank is made from a steel drum volumed 200 liter tank and collector tank from a steel drum volumed 120 liter. Digester tank serves as a reservoir and the ongoing process of anaerobic fermentation of materials. Collector tank serves as a reservoir of the formed biogas.Insulator tank delivers the formed gas in collector tank to the user component of biogas, such as biogas stove. The three drums are connected via a rubber hose for gas distribution. Hose used in this observation is a powerful compressor hose to prevent leaks [5].

\section{Research Implementation}

In this testing phase, the raw material used is a mixture of organic waste and water with organic waste and water ratio is 1:1 [10]. The research was carried out with two treatments, namely: (a) The first treatment with a mixture of radish and mustard, with ratio of 1:1. (b) Second treatment with raw cabbage.

\section{Preparation of Raw Materials}

Packing material is a mixture of organic waste and water with ratio of $1: 1$. Organic waste to be used as packing material have reduced size, blended with water and free from hard objects such as rocks, gravel, plastic and so on.

Raw material of the organic waste, namely a mixture of radish and mustard (35 kgs each) and mustard (70 kgs).
The process of size reduction can be the cutting with a knife or comminution of raw materials by hand, so its size is smaller and softer.

\section{Filling Raw Materials}

Addition of starter substance to the mix of raw materials to accelerate decomposition. Starter substance used is EM4 as much as 4 liters for each treatment.

Once the raw materials had been reduced in size, put in a digester tank then the water that has been mixed with EM4 through inlet.

Spending faucet at the top of the tube digester is opened so that the gas flow can then be formed into a collector tube.

Insulator tank had been prepared without the collector tank and then filled with water and the faucet pipe at the collector tank is closed in order to ensure the formed gas and the deposited one is not wasted to the outside.

\section{Observation}

\section{Knowing Commencement Time Produce Biogas}

This observation is calculated from the first day of importation of raw materials or organic waste into a tube reactor. The gas that begins to form from the digestion of raw materials in the reactor tube is characterized by an increase in the collector tank.

2. Knowing the volume and pressure of Biogas Generated

Observation of volume and pressure will be performed daily at 10:00 AM for a month, which observe the increase in the volume and pressure of the biogas in collector tank. Selected at $10 \mathrm{AM}$ because the temperature tends to stable (room temperature). If the volume and pressure in the tank increases, the gas produced is increasing, i.e. by the equation :

$$
\begin{aligned}
& \mathrm{V} \text { gas }=\pi . \mathrm{r} 2 . \mathrm{t} \\
& \begin{array}{ll}
\text { description: } & \\
\mathrm{V} \text { gas } & =\text { gas volume }\left(\mathrm{m}^{3}\right) \\
\mathrm{T} & =\text { high rise collector tank }(\mathrm{m}) \\
\mathrm{r} & =\text { radius of the collecting tank }(\mathrm{m})
\end{array}
\end{aligned}
$$

Pressure is calculated by the formula:

$$
\text { Pressure of gas }=
$$

$$
\frac{\mathrm{n}}{10,33 \mathrm{~m}} \times 101.325 \mathrm{~Pa}
$$

$$
\begin{aligned}
& \text { description: } \\
& \begin{array}{ll}
\mathrm{n} & =\text { height difference of the water column }(\mathrm{m}) \\
10.33 \mathrm{~m} & =1 \mathrm{~atm}(10.33 \mathrm{~m} \text { water column })
\end{array}
\end{aligned}
$$

In observation of the pressure in the collector tank, it can be seen by observing whether the collecting tank has increased.

\section{The Energy Generated by the Biogas}

Energy to boil water can be calculated by the equation:

$$
\mathrm{q}=\mathrm{m} \text {. c. } \Delta \mathrm{t}
$$

$$
\begin{array}{ll}
\text { description: } & \\
\mathrm{q} & =\text { amount of energy to boil water (joules) } \\
\mathrm{m} & =\text { period of boiled water }(\mathrm{kg}) \\
\text { water } \mathrm{c} & =\text { specific heat of water }\left(\text { calories } / \mathrm{kg}{ }^{\circ} \mathrm{C}\right)
\end{array}
$$



$\Delta \mathrm{t}=\begin{aligned} & \text { difference between boiling temperature and the } \\ & \text { room temperature }\left({ }^{\circ} \mathrm{C}\right)\end{aligned}$

\section{Environmental Temperature and Relative Humidity}

The average temperature can be measured with a thermometer. The data taken during the production of biogas, that is for 30 days. Observations of Relative humidity (RH) obtained using psychrometric chart.

\section{Biogas Productivity}

Productivity (liters / raw materials) obtained by the formula :

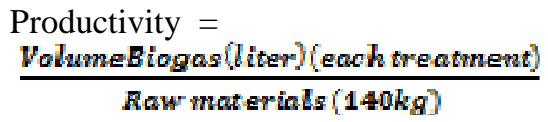

\section{The degree of acidity of Raw Materials $(\mathrm{pH})$}

To determine the degree of acidity $(\mathrm{pH})$ of the material contained in the reactor tubes, the $\mathrm{pH}$ of sampling raw materials to be measured is done during the production of biogas that will occur in a tube reactor or on the $30^{\text {th }}$ day of observation. PH measurements of raw materials carried out at the Soil Laboratory of Agriculture Faculty, Andalas University, using a $\mathrm{pH}$ meter.

\section{RESULT AND DISCUSSION}

\section{A. Knowing The Commencing Time of Producing Gas}

Data observations can be seen in Table 1 .

TABLE I

COMMENCING TIME OF PRODUCING GAS

\begin{tabular}{|c|c|}
\hline Raw Material & $\begin{array}{c}\text { Commencing Time of Producing } \\
\text { Biogas (Days) }\end{array}$ \\
\hline Radish and mustard (ratio 1:1) & 9 \\
\hline Mustard & 9 \\
\hline
\end{tabular}

Based on Table 1, the commencing time from the creation of gas for both treatments is same, on 9th day. When gas was beginning to form or produced, then the collector tank included in the insulator tank filled with water would lift due to pressure from gas that flowed into the collector tank. Duration time to produce biogas from the inclusion of raw material (organic waste mix with water) into the reactor tank was also influenced by the water, the $\mathrm{pH}$ of the raw materials, and ambient temperature. Fermentation dwell time is the time required in the fermentation of organic waste to produce gas. Fermentation time that is 7 days, 9 days, 12 days, 15 days, 18 days, and 21 days and in the early stages of fermentation the bacteria breed to live and decompose organic waste [6].

The gas produced flows itself into the gas collector tank. By usingwater push force in the insulator tank, then the mass of collector tank can be lifted with the increase of biogas production and with the pressure of the gas from the collector tank, the gas can be discharged into biogas stove.
The commencing time of producing biogas from cattle feces is on the 7th day [5]. This is due to the cattle feces contains cellulase enzyme cattle as decomposers, so the decomposition occurs faster thanthe organic waste that require EM4 as decomposers.

\section{B. Volume and Pressure of Biogas Produced}

Volume and pressure observations performed every day at $10.00 \mathrm{AM}$, and the observations is done in 30 days for each treatment. Graphics gas volume produced in each treatment can be seen in Figure 1.

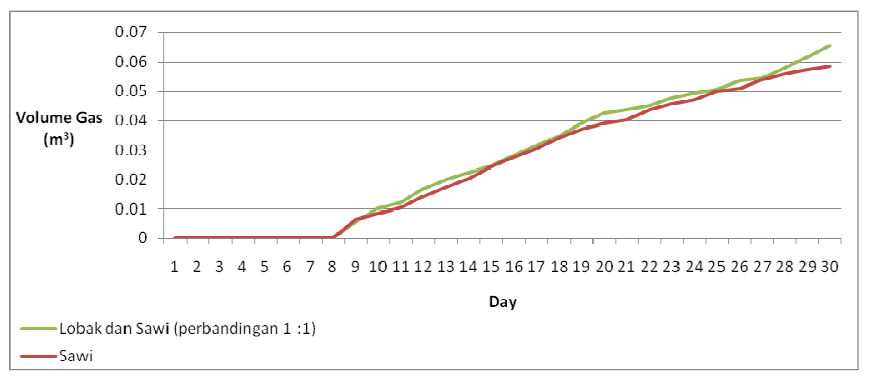

Fig. 1 The Increase of Biogas Volume

In Figure 1, on treatment I (radish and mustard) saw the highest increase involume occurredon 9th day with a volume of 5.61 liters. Although the increase involume continues to raise, but after the 9th day the increase in gas volume shrinking. This was caused bythe gascreatedin the digester tube thinning so the volume of collector tube decreasing.

In treatment II (raw materials mustard), volume began to take shapeon 9th day with a volume of 6.33 liters. Totalvolume of biogas obtained intreatment is 65.84 liter sand in treatment II is 58.60 liters. With raw material of cattle feces volumed 180 liters produces 87.75liters of biogas [5].

Although relatively small, butthe volume of biogas of both treatmentsin Figure1continue to increaseuntil the 30th day. The high and low of volume is also affected by the capacity of raw materials by the reactor. The higher capacity of the reactor, the greater volume produced. Vice versa.

According Fairus, Salafudin, Lathifa and Emma (2011), a material that can be distributed to the water depends on the particle size of a substance. The verysmall size of particle of very helpfulin the process of dissolvingorganic materials to decompose the organic substance into the organic acid that converted into $\mathrm{CH}_{4}$ and $\mathrm{CO}_{2}$. Large volume of biogas can not assure that them ethane gas produced is large too.

The change of biogas pressure in both treatments increased during 30 days of observation. Pressure can be calculated by inserting the data of water column high difference on insulator tank into the formula (2). Graphics biogas pressure presented in Figure 2. 


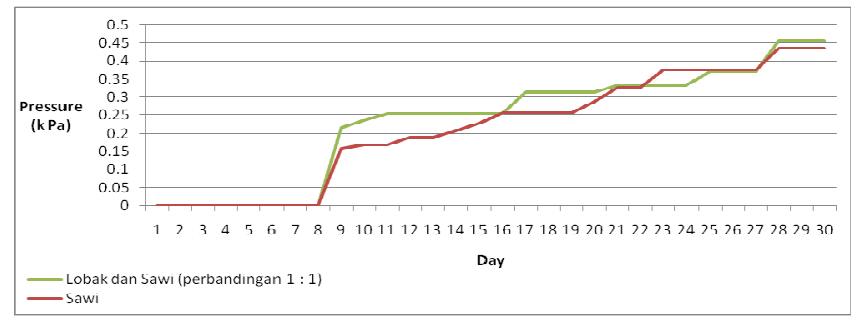

Fig. 2 Gas Pressure

In Figure 2, on treatment $\mathrm{I}$ it seen the early pressure occurredon 9th day with the pressure of $215.8 \mathrm{~Pa}$ and on 30 th day the pressure is $456.1 \mathrm{~Pa}$. If associated with Figure 1 it is shown that along with the increasing in volume, the value of pressure increased too. The volume and pressure are equally created in the 9th day and then continue to increase. This occurs because the mass increment in collector tank so the increasing mass causing the higher pressure.

In treatment 2, pressure is seen on 9th day with the value of $158.6 \mathrm{~Pa}$. If the volume of gas is increasing, then the higher the gas pressureand, vice versa. However, on treatment 1 it can be seen that the increasing pressure on $11^{\text {th }}$ day decreased. This is caused by the necessity of energy or greater pressure to lift or push objects in fluenced by gravity.

\section{Relative Humidity and Temperature Range}

The calculation of relative humidity $(\mathrm{RH})$ can be seen in Table 3. The average value of RH fromTreatment I is $80.1 \%$ and from Treatment II is $82.1 \%$. RH values obtained by using the input data to the ambient temperature in the psychrometric chart.

Ambient temperature observations is made at $10.00 \mathrm{~A} \mathrm{M}$ around the biogas reactor for the biogas production process. The results carried out for 30 days in two treatment can be seen in the graph the temperature range fort he production of biogas in Figure 3 and 4.

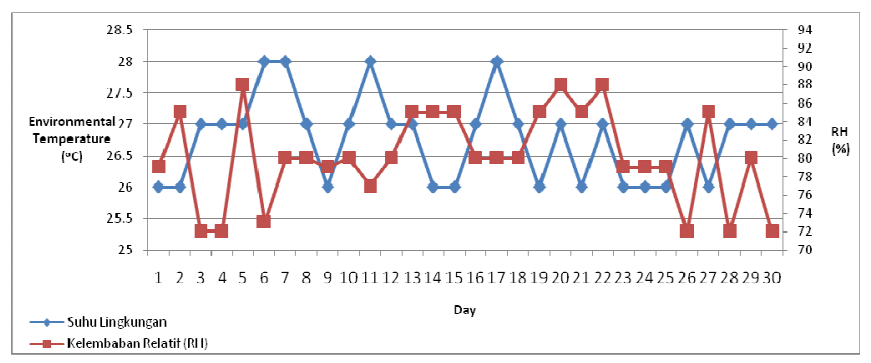

Fig. 3 Environmental temperature and RH in the Treatment I

In Figure 3, the highest temperature seen is $28{ }^{\circ} \mathrm{C}$ and lowest is $26{ }^{\circ} \mathrm{C}$. The average value of the ambient temperature was $26.8{ }^{\circ} \mathrm{C}$. RH values obtained for treatment I at $80.1 \%$. Based on Figure 3, we can see the difference in temperature is not too far away, from $26-28{ }^{\circ} \mathrm{C}$. Temperature chart for the treatment IIcan be seen in Figure 4.

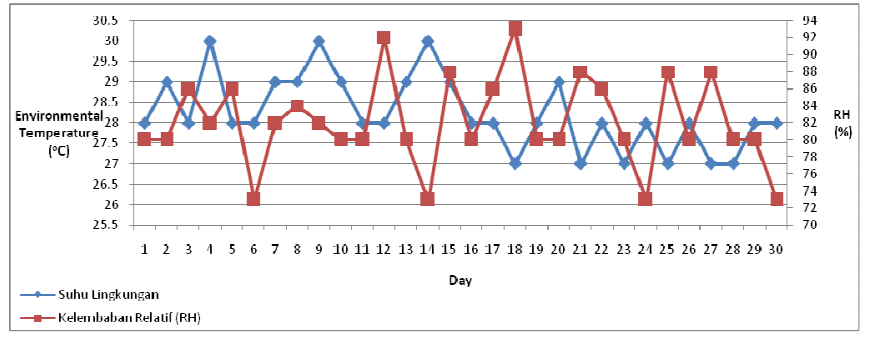

Fig. 4 Environmental temperature and RH in the Treatment II

In Figure 4, it appears that the highest temperature is $30{ }^{\circ} \mathrm{C}$ and the lowest is $27{ }^{\circ} \mathrm{C}$. The average temperature is $28.2{ }^{\circ} \mathrm{C}$. $\mathrm{RH}$ value in treatment II is $82.1 \%$. In treatment II, the average environmental temperature is higher than the treatment I, $28.2{ }^{\circ} \mathrm{C}$. This is because the weather at the time of data collection treatment II is higher so the $\mathrm{RH}$ in treatment II is lower than in treatment I.

According to Paimin [7], the good temperature for the formation of a biogas ranging between $20-40{ }^{\circ} \mathrm{C}$, with an optimum temperature of $28-30{ }^{\circ} \mathrm{C}$. Thus, the temperature in production of biogas must be maintained so that the formation of biogas temperature is at the optimum temperature to produce optimal biogas for the production of biogas. From the calculations, the average value wet bulb temperature, dry bulb temperature and relative humidity $(\mathrm{RH})$ is obtained for the two treatments as in Table 2.

TABLE II

MEAN ENVIRONMENTAL TEMPERATURE AND RELATIVE Humidity (RH)

\begin{tabular}{|l|c|c|}
\hline \multirow{2}{*}{ Environmental Parameter } & \multicolumn{2}{c|}{ Treatment } \\
\cline { 2 - 3 } & I & II \\
\hline Environmental temperature $\left({ }^{\circ} \mathrm{C}\right)$ & 26,8 & 28,2 \\
\hline Relative Humidity $(\%)$ & 80,1 & 82,1 \\
\hline
\end{tabular}

Based on Table 2, the wet bulb temperature can be seen from the two treatments ranged $24{ }^{\circ} \mathrm{C}$ and dry bulb temperatures around $27{ }^{\circ} \mathrm{C}$. According to Paimin [7], the good temperature for the formation of a biogas ranging between $20-40{ }^{\circ} \mathrm{C}$. Thus, the temperature in production of biogas must be maintained so that the formation of biogas temperature is at the optimum temperature to produce optimal biogas for the production of biogas. Thus, the temperature obtained is a good temperature for the formation of biogas.

\section{The Energy Generated by The Biogas}

The energy produced by biogas can be calculated by boiling the water. After doing research, the amount of water that can be boiled is as much as $2 \mathrm{kgs}$ in each treatment at different temperatures. The energy data is shown in Table 3.

TABLE III

ENERGY GENERATED

\begin{tabular}{|c|c|}
\hline Treatment & Energy Generated $(\mathrm{kJ})$ \\
\hline I & 554,4 \\
\hline II & 537,6 \\
\hline Average & 546 \\
\hline
\end{tabular}


In Table 3 , it can be seen that the $2 \mathrm{kgs}$ water does not boil or just reach $93{ }^{\circ} \mathrm{C}$ in treatment I and $92{ }^{\circ} \mathrm{C}$ in treatment II. The average energy generated from two treatments is 546 $\mathrm{kJ}$. The boiling point of water is affected by the altitude above sea level of testing location, such as boiling water sample will be different when cooked in lowland water, where it will be higher than the boiling point of water in the low land high. According to Guska [5], biogas obtained from 180 liters of cattle feces is $10,017 \mathrm{~kJ}$.

Methane gas is odorless and colorless, with a boiling point of $162{ }^{\circ} \mathrm{C}$, which produces a blue flame and can burn easily. Density of methane gas is around $0.75 \mathrm{~kg} / \mathrm{m}^{3}$. The energy contained in methane is $39.8 \mathrm{MJ} / \mathrm{m}^{3}$, equivalent to $11.06 \mathrm{kWh} / \mathrm{m}^{3}[4]$.

\section{E. The Degree of Acidity of Materials $(\mathrm{pH})$}

PH measurements performed on the first and last day by using a pH meter, the result can be seen in Table 4 .

TABLE IV

PH VALUE OF MATERIALS

\begin{tabular}{|c|c|c|c|}
\hline \multicolumn{3}{|c|}{ Treatment } \\
\cline { 2 - 4 } Materials pH & I & II & Average \\
\hline Early pH & 6.1 & 6.3 & 6.2 \\
\hline Final pH & 6.6 & 6.8 & 6.7 \\
\hline
\end{tabular}

The $\mathrm{pH}$ testing of samples taken on the first and the $30^{\text {th }}$ observation day. In the first treatment with raw radish and mustard it obtained initial $\mathrm{pH}$ value of 6.1. As long as the $\mathrm{pH}$ is in the acid, production of biogas and $\mathrm{CH}_{4}$ will continue. The good $\mathrm{pH}$ values for biogas production is above 6 . Therefore, the $\mathrm{pH}$ of the raw material at the time of the biogas production should be above 6 , because if the $\mathrm{pH}$ value below 6 , the biogas production will not run optimally. According Budihardjo (2012), the process of methanogenesis by bacteria that use $\mathrm{CO}_{2}$ and $\mathrm{CO}$ as the substrate is very sensitive to the changes in $\mathrm{pH}$.

The degree of acidity is very influential to the lives of microorganisms. In the early stages of fermentation, organic material will form acids (organic acids) which lowers the $\mathrm{pH}$. To prevent a decrease in $\mathrm{pH}$, it can be done by adding a lime solution $\left(\mathrm{Ca}(\mathrm{OH})_{2}\right.$ or $\mathrm{CaCO}_{3}$ [8]. According to Yunus [11], the anaerobic fermentation of organic waste is dominated by methane formation stage (methanogenesis), which methanogenic bacteria working more efficiently at $\mathrm{pH}$ of 6.2 to 7.8 .

In the first to the second week, hydrolysis process occurs which indicates the high activity of microorganisms in decomposing organic polymers into soluble monomers done by a group of facultative bacteria [9].

\section{F. Productivity of Generated Biogas}

From the observations done in 30 days, the total volume of biogas obtained is shown in Table 5 .

TABLE V

Productivity Of Generated Biogas

\begin{tabular}{|c|c|}
\multicolumn{2}{|c|}{ PRODUCTIVITY OF GENERATED BIOGAS } \\
\hline Treatment & $\begin{array}{c}\text { Productivity } \\
\text { (liter per kg of materials) }\end{array}$ \\
\hline I & 0.47 \\
\hline II & 0.42 \\
\hline Average & 0.445 \\
\hline
\end{tabular}

Table 5 shows the value of the productivity of the first treatment, i.e. with raw radish and mustard greens (ratio 1:1) has the highest productivity. So, with the addition of radish as material, then the productivity of the gas produced is higher than just raw mustard only.

A material to be distributed by water depends on the particle size of the material. Small particle size is very supportive in the process of dissolving the organic material to decompose organic matter into organic acids which are then converted into $\mathrm{CH}_{4}$ and $\mathrm{CO}_{2}$ (Fairus, Salafudin, Lathifa and Emma, 2011).

\section{CONCLUSIONS}

Based on this research, the first treatment with raw radish and mustard mixture with a ratio of $1: 1$ obtained $554.4 \mathrm{~kJ}$ biogas energy and biogas productivity of 0.47 liters $/ \mathrm{kg}$ of raw material. The commencing time to produce biogas is at $9^{\text {th }}$ day, ambient temperature of $26.8^{\circ} \mathrm{C}$, relative humidity of $80.1 \%$, gas pressure of $456.1 \mathrm{~Pa}$, initial $\mathrm{pH}$ of 6.1 , and the final $\mathrm{pH}$ of 6.6 .

In the second treatment with mustard raw materials obtained $537.6 \mathrm{~kJ}$ biogas energy and biogas productivity of 0.42 liters $/ \mathrm{kg}$ of raw material. The commencing time to produce biogas is at $9^{\text {th }}$ day, with the ambient temperature of $28.2{ }^{\circ} \mathrm{C}$, relative humidity of $82.1 \%$, gas pressure of 436.2 $\mathrm{Pa}$, initial $\mathrm{pH}$ of 6.3 , and the final $\mathrm{pH}$ of 6.8 .

Of the two treatments, the first treatment produces energy and productivity and higher than the second one with raw materials of radish and mustard mixture in the ratio of 1:1.

When compared to the production of biogas with cattle feces materials with results in a volume of 87.75 liters, biogas energy of $10017 \mathrm{~kJ}$ and productivity of 0.4875 liters $/ \mathrm{kg}$ of raw material [5], the results were lower due to cattle feces materials have a natural decomposing bacterias o that the process of formation of the gasis more optimal.

\section{REFERENCES}

[1] Exantas Tehnologie Alimentara. 2012. Bioenergy. http://bioenergy.exantas.ro/pages.php?page=biogazul (11 April 2012).

[2] Guska, Andri. 2009. Pengembangan Model Bioreaktor Biogas dari Drum[essay]. Faculty of Agricultural Technology. Andalas University. Padang.

[3] Khoirul, A. dan J. Bunga. 2006. Penentuan Produktivitas Biogas pada Berbaghai Limbah Organik dengan Proses Fermentasi Anaerobik. Chemical Engineering. ITENAS. Bandung.

[4] Paimin, B. Farry. 1999. Alat Pembuatan Biogas dari Drum. Penebar Swadaya. Jakarta.

[5] Simamora, S., Sahmdik, Sri. W., Surajudin. 2006. Membuat Biogas. Agro Media Pustaka. Jakarta.

[6] Sudradjat, H.R. 2006. Mengelola Sampah Kota. PT. Penebar Swadaya.Jakarta.

[7] Wahyuni, Sri. 2008. Biogas. PT. Penebar Swadaya. Jakarta.

[8] Yunus, M. 1987.Teknik Membuat dan Memanfaatkan Unit Gas Bio. Gadjah Mada University Press. Yogyakarta. 